\title{
THE EDITION EFFECT OF NATURAL FIBERS ON POLYMERIC MATERIALS AND STUDY SOME OF THERMAL AND MECHANICAL PROPERTIES
}

\author{
Raghad Hussein Mohammed, Mustafa Amer Hassan and Noor Sabah Sadeq \\ Materials Science Branch, Department of Applied Science, University of Technology.
}

\begin{abstract}
This research has been done by reinforcing the matrix (polyester) resin with natural material (frond palm). The fibers were exposure to chemical treatment before reinforcement.

Different volume fractions were used $(0 \%, 15 \%, 20 \%)$. After preparation of composite material some of the physical properties have been studied of samples preparation. They were Tensile strength test, Impact test, and Thermal conductivity.

The thermal conductivity was studied, the values of thermal conductivity were increased with increasing of volume fraction of all specimens and also the tensile strength and flexural strength were decreased with increasing volume fraction of fibers, while the impact strength was increased with volume fraction $15 \%$ but with continuouity of reinforcement, the impact strength was decreased, and also the chemical treatment of fibers improved the mechanical and thermal properties.
\end{abstract}

\section{Introduction}

Over the past few decades, polymers have replaced many of the conventional metals/ materials in various applications. This is possible because of the advantage of polymers offer over conventional materials. The most important advantages of using polymers are the ease of processing, productivity and cost reduction. Collectively, polymer composites are light, stiff, strong and low both large and small scale production at lower energy costs. The light weights of these composites also increase the energy efficiency for machine and transportation [1].

Natural fiber reinforced composites is an emerging area in polymer science. These natural fibers are low cost fibers with low density and high specific properties. The natural fiber composites offer specific properties comparable to those of conventional fiber composites [2].

The physical properties of natural fibers are mainly determined by their chemical and physical composition, such as structure of fibers, cellulose content, angle of fibrils, and cross section, and by the degree of polymerization.[3].

The thermal behavior is dependent on the nature of the fiber used [4].

Various applications of natural fibers as reinforcement in plastics have proved encouraging. Several natural fiber composites reach the mechanical properties of glass-fiber composites, and they are already applied, e.g. in automobile and furniture industries [5].

Unsaturated polyesters are extremely versatile in properties and application and have been a popular thermoset used as the polymer matrix in composites. They are widely produced industrially as they possess many advantages compared to other thermosetting resins including room temperature cure capability, good mechanical properties and transparency. Curing of unsaturated polyester is due to a polymerization reaction that causes cross linking among individual linear polymer chains. In contrast to other thermosetting resins, no by-product is formed during the curing reaction, hence resins can be molded cast and laminated at low pressure and temperature [6].

The palm fibers in date production have filament textures with special properties such as: low costs, plenitude in the region, durability, lightweight, tension capacity and relative strength against deterioration. Thus, it is possible to use the palm fibers as an alternative low cost natural material for soil reinforcement [7]. 


\section{Experimental Methods:}

\section{Materials}

The polyester used was an unsaturated polyester resin, that was obtained from AlSaudi Company of industrial resin limited. The frond fibers obtained from palm tree was used in this study.

\section{Fibers treatment:}

Frond fibers was cut into (20) $\mathrm{cm}$ length and (3) $\mathrm{mm}$ width, then the fibers rinsed in water and left to dry at room temperature before being put in an oven for 3 hours at $50{ }^{\circ} \mathrm{C}$. After that frond fibers were soaked in (polyester resin / solvent) solution with ratio (70:30) in glass receptacle at room temperature for 48 hour, see Fig.(1). The fibers was left to dry at room temperature before being used.

\section{Preparation of composite:}

Composite was made using a stainless steel mould having dimensions $(20 \times 20 \times 1) \mathrm{cm}^{3}$ length, width respectively. The composites were prepared by varying the relative volume fraction of fibers $\left(0 \mathrm{~V}_{\mathrm{f}}, 15 \mathrm{~V}_{\mathrm{f}}, 20 \mathrm{~V}_{\mathrm{f}}\right)$. The ratio of hardener which was added to polyester is (98:2), every 98 gm from polyester adding (2) gm hardener, then mixed the solution very well before poured it to obtain homogeneity.

The frond fibers were put in mould and the resin poured onto fibers. That process repeated with another second volume fraction. The mould left for 48 hour to get solid samples. Then the mould was heated for $50{ }^{\circ} \mathrm{C}$ for 3 hour to complete the curing process, see Fig.(2).

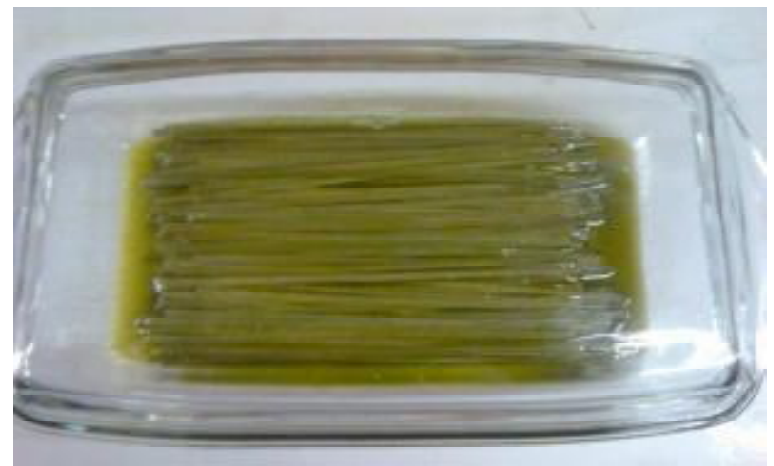

Fig.(1) : Chemical treatment of fibers.
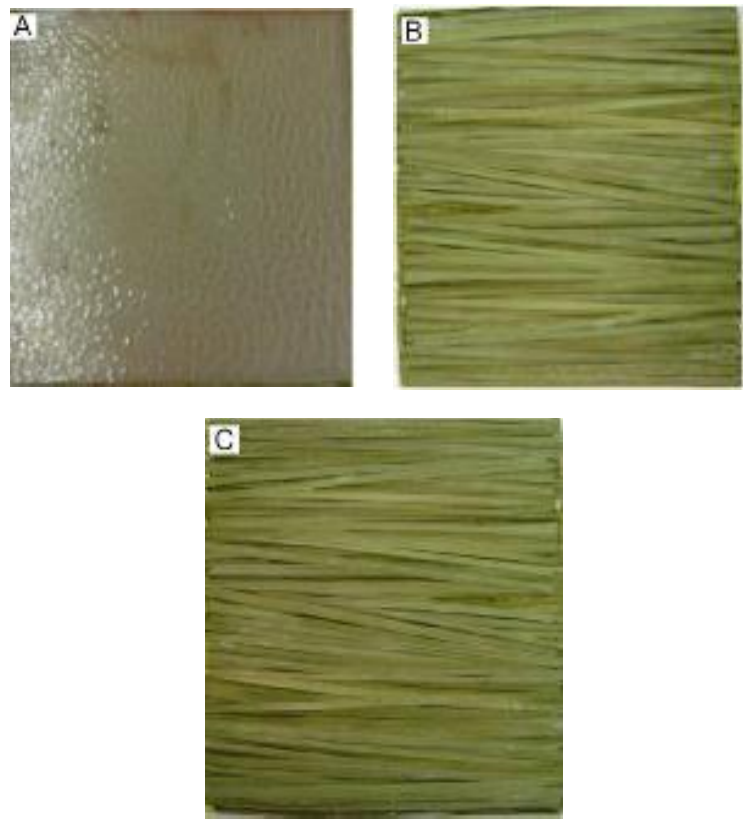

Fig. (2) : Samples of production, $A$ with $V_{f} 0 \%, B$ with $V_{f} 15 \%$, $C$ with $V_{f} 20 \%$.

\section{Measurements}

In this work Charpy impact test was used. The dimensions of specimens, width and thickness were measured and recorded, see Table (1). The test was carried out in accordance with ISO-179. The impact strength value was calculated by dividing the energy in $\mathrm{KJ}$ recorded on tester by cross sectional area of specimen.

Thermal conductivity test was used. The test was carried out in accordance with Lee s disk. Lee's disk device is used to calculate (K) values for non-conductive materials (disk shape). The specimen ( $\mathrm{S}$ ) is placed between two copper disk (A, B). Disk B shall be contacted to electrical heater and then comes the copper disk (C) which represents the thermal conductivity device.

Flexural (bending) test was used in this work. The dimensions and thickness of specimen were measured and recorded. The test was carried out in accordance with ASTM D-790. The flexural modulus was calculated from this test.

The tensile test was used in this work. The length of specimen is $(57 \mathrm{~mm})$. The thickness and width were measured and recorded. Tensile load is applied at a rate ( 0.5 ton). The velocity of pulling is (1 $\mathrm{mm} / \mathrm{min})$ and by 
utilization of the connected graphic plotter, the relation of $(\mathrm{p}-1)$ is obtained. This relationship would be modified to relation of (stressstrain) curve to calculate the ultimate tensile strength (UTS) for the specimens. The test was carried out in accordance with ASTMD638M.The maximum (peak) load (Fmax) was recorded.

The following specimens have been obtained, see Fig.(3) :

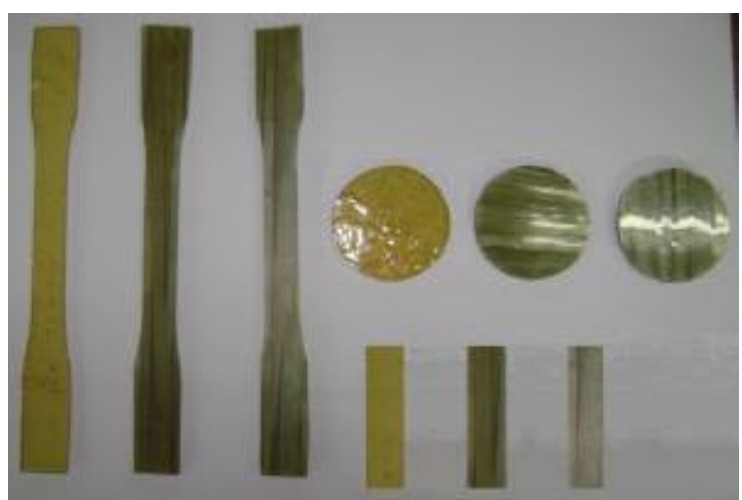

Fig. (3) : Form of the test requirements for thermal conductivity, impact and tensile tests.

\section{Discussion}

\section{Thermal Conductivity Test}

Thermal conductivity $(\mathrm{K})$ is defined in terms of the quantity of heat that will flow per second divided by the temperature gradient [8].

The results obtained for the thermal conductivity of the specimens are shown in Table (2). The thermal conductivity of these specimens was measured perpendicular to the fibers orientation.

The values of thermal conductivity for both composites are higher than of this for the resin matrix, because frond palm fibers have a thermal conductivity of $\left(0.743 \mathrm{~W} / \mathrm{m} .{ }^{\circ} \mathrm{C}\right)$. which is higher than the resin matrix. Moreover the results reveal that the samples exposure to the chemical treatment have high value of the thermal conductivity than that of the other samples which doesn't exposure chemical treatment.

Increasing of values of thermal conductivity could be observed with the increasing of volume fraction for fibers. The specific heat was increased with the increase of thermal conductivity according to the equation: [4]

$$
\mathrm{C}=\mathrm{K} / \mathrm{d}
$$

Where $\mathrm{C}$ : is specific heat, $\mathrm{K}$ is thermal conductivity and $\mathrm{d}$ is the thermal diffusivity. This results can be explained as this type of fibers are long and oriented which lead to increase thermal conductivity for the composite material with the increase of volume fraction of fibers. These fiber works as continuous paths for flow of the heat flux which allows to: heat transferring along the fibers and increasing the number of touch points between fibers.

\section{Impact Test}

Charpy impact test was used to measure the impact strength, which may be defined a toughness or ability of material to absorb energy during plastic deformation. Toughness takes into account both the strength and ductility of the material [9].

The direction of the applied force is perpendicular to the fiber orientation.

Impact strength of composite depends on the amount of fiber and the type of testing, the impact strength increases with the amount of fibers added. The results show the impact strength increases with the amount of fibers added until a volume fraction is reached at about $20 \%$ fiber. The presence of fibers decrease the energy absorbed by the specimens, addition of the fibers creates regions of stress concentrations that require less energy to initiate a crack [10].

In general, an increase in fracture energy was accompanied by increasing fiber toughness [11].

These results well agreed with Sharifah $\mathrm{H}$. Aziz et al (2005). Where found Charpy impact strength decreases with enhanced fiber matrix adhesion. For a treated fiber composites, the interfacial friction stress between matrix and fiber is generally higher when compared to composites with untreated fibers and this causes a drop in toughness (5).

\section{Tensile and flexural strength tests}

Fig. (4) shows the tensile behavior of composites samples under tensile test. Young's modulus, ultimate tensile strength and flexural strength decreased as increasing 
of volume fraction of fibers because of the incompatibility between natural fibers and resin matrix.

The effect of the frond palm fiber loading on the flexural strength is shown in the Table (2). The flexural strength decreases as the fiber loading increasing. However, in general the higher volume fraction of fiber decreases the flexural strength compared with smaller volume fraction.

Sreekala et al., (2002) they found the significant decrease in the flexural strength is observed at the highest EFB fiber volume fraction of $100 \%$ which is due to the increased fiber-to-fiber interactions and dispersion problem which results in low mechanical properties of composites [12].
The stresses concentration were accumulate at the weakness regions where the low adhesion forces between the matrix and the fibers. Despite of chemical treatment of fibers the results show tensile strength of pure sample has higher value than others samples. These results can be explained due to lack of interfacial bonding between frond fiber and polymeric matrix.

The treated sample with $\mathrm{V}_{\mathrm{f}} 15 \%$ has higher tensile strength than the untreated sample with $\mathrm{V}_{\mathrm{f}} 15 \%$. These results well agreed with $\mathrm{X}$. Li, S.A. Panigrahi et al (2004) they found all composite samples reinforced with chemically pretreatment flax fiber had higher tensile strength than composites reinforced with untreated flax fiber [13].

Table (1)

Shows the standards of specimens for mechanical tests.

\begin{tabular}{|c|c|c|}
\hline Specimen & Standard dimensions of specimen & Standards \\
\hline $\begin{array}{l}\text { 1.Tensile } \\
\text { strength }\end{array}$ & 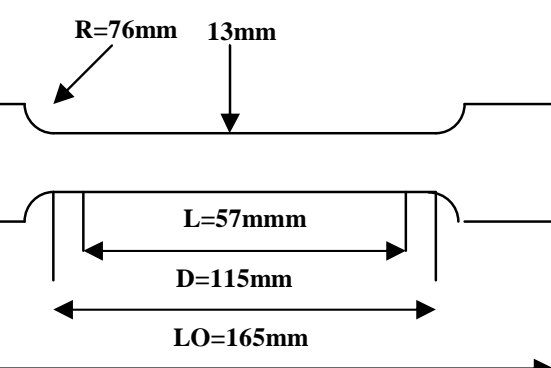 & ASTM -D638M \\
\hline $\begin{array}{l}\text { 2.Impact } \\
\text { strength }\end{array}$ & $\underset{55 \mathrm{~mm}}{\longrightarrow}$ & ISO-179 \\
\hline $\begin{array}{l}\text { 3.Thermal } \\
\text { conductivity }\end{array}$ & $40 \mathrm{~mm}$ & Lee's Disc \\
\hline
\end{tabular}




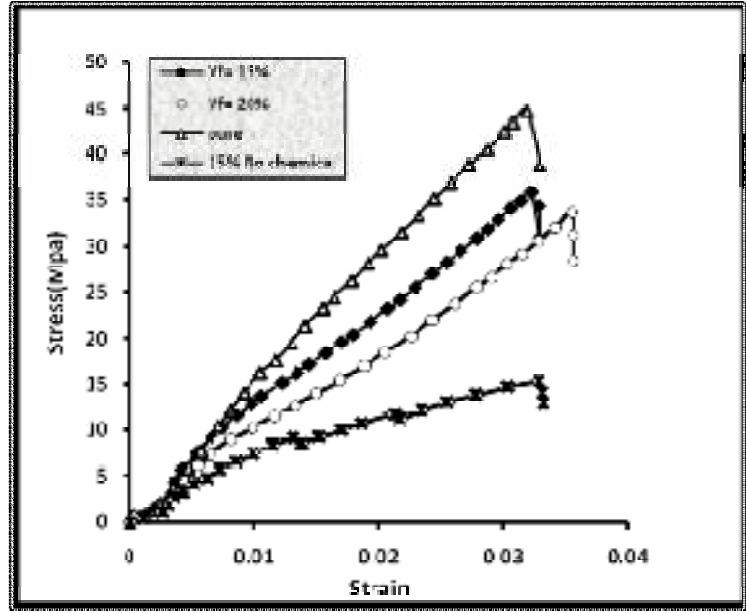

Fig. (3) : Show (Stress-Strain) of composite reinforced with frond palm fibers with different volume fraction.
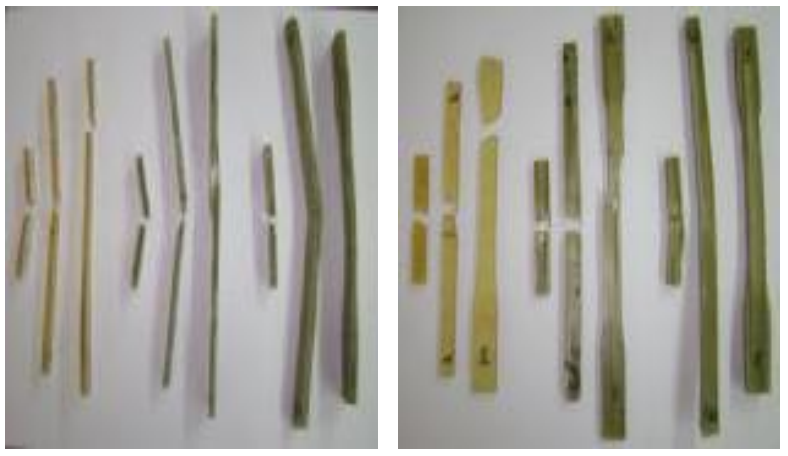

Fig. (4) : Samples with tensile test and impact test after used( The picture show the fractures of all samples are brittle).
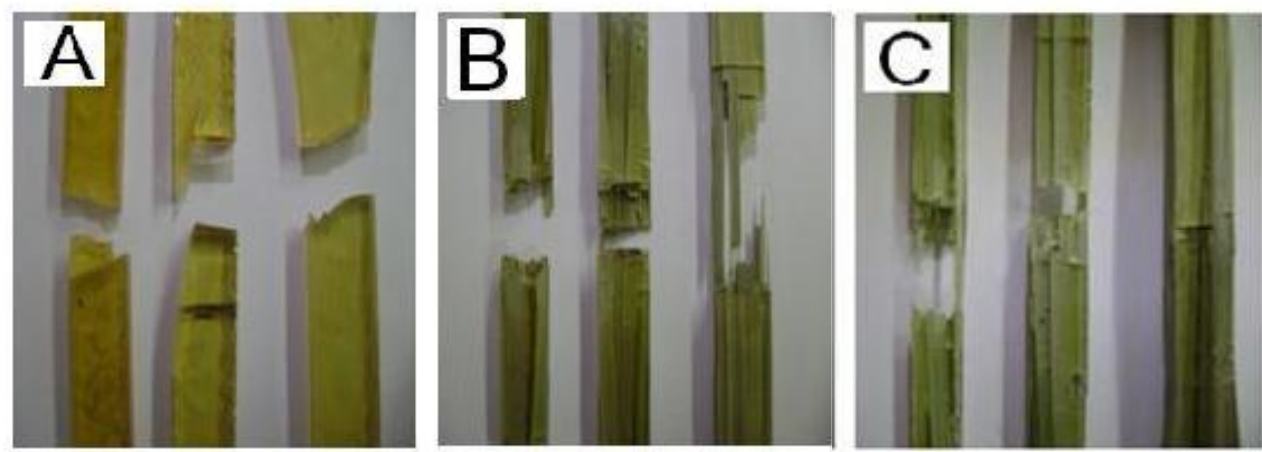

Fig. (5) : The shape of fracture of all samples, $A$ with $V_{f} 0 \%, B$ with $V_{f}$ $15 \%, C$ with $V_{f} 20 \%$.

Table (2)

Shows some of thermal and mechanical test.

\begin{tabular}{|c|c||c||c||c|c||}
\hline $\begin{array}{c}\text { Samples } \\
\text { With } \\
\text { chemical } \\
\text { treatment }\end{array}$ & $\begin{array}{c}\text { Thermal } \\
\text { Conductivity } \\
\mathbf{W} / \mathbf{m} .{ }^{\circ} \mathbf{C}\end{array}$ & $\begin{array}{c}\text { Impact } \\
\text { Test } \\
\left(\mathbf{K}_{\mathbf{J}} \mathbf{m}^{\mathbf{2}}\right)\end{array}$ & $\begin{array}{c}\text { Young's } \\
\text { Modulus } \\
(\mathbf{M P a})\end{array}$ & $\begin{array}{c}\text { Ultimate } \\
\text { Strength } \\
(\mathbf{M P a})\end{array}$ & $\begin{array}{c}\text { Flexural } \\
\text { Strength } \\
(\mathbf{M P a})\end{array}$ \\
\hline $0 \%$ & 0.255 & 7.41 & 1480 & 44.78 & 457.217 \\
\hline \hline $15 \%$ & 0.322 & 9.45 & 1285.8 & 35.84 & 326.98 \\
\hline $20 \%$ & 0.357 & 8.57 & 958.95 & 33.66 & 320.07 \\
\hline \hline $\begin{array}{c}\text { Untreated } \\
\text { Sample } \\
\text { With 15\% }\end{array}$ & 0.264 & 7.16 & 728.93 & 15.27 & 311.03 \\
\hline
\end{tabular}




\section{Conclusion}

1) The addition of frond palm fibers decreases Young's modulus, impact strength, tensile and flexural strength but the addition of that fibers increases thermal conductivity.

2) The mechanical properties of composites are influenced mainly by the adhesion between matrix and fibers. which increases with strong adhesion between them .

3) The chemical treatments of the fibers improvement the mechanical and thermal properties of fibers because of improve the compatibility bonding between fiber and matrix but still lack of interfacial bonding between frond fibers and polymeric matrix.

\section{References}

[1] Karina Myrtha, Onggo Holia, Dawam Abdullah A. H.\& Syampurwadi Anung, “' Effect of Oil Palm empty Fruit Bunch Fiber on the Physical and Mechanical Properties of Fiber glass Reinforced Polyester Resin", Journal of Biological Sciences, Vol. 8, No.1, P.P( 101-106), 2008.

[2] Saheb D. Nabi, Jop J. P., " Natural fiber Polymer composites : A review ", Advances in Polymer Technology, Vol.18, Issue 4, P.P.( 351-363), 2007.

[3] Idicula. Maries, Neelakantan. N. R., Oommen. Zachariah, Joseph. Kuruvilla, Thomas Sabu," A study of the Mechanical Properties of Randomly Oriented Short Banana and Sisal Hybrid Fiber Reinfrced Polyester Composites", Journal of Applied Polymer Science, Vol. 96, No. 5, P.P.(1700-1709), 2005.

[4] Alsina O. L. S., De Carvalho L.H., Filho Ramose F. G., D' Almeida J. R. M., "Thermal properties of Hybrid Lignocellulosic Fabric-reinforced polyester matrix composites", Polymer Testing Vol.24, P.P.(81- 85), 2005.

[5] A.K. Bledzki, J. Gassan, "Composites reinforced with cellulose based fibres", Prog. Polymer. Science, Vol.24, P.P.(221274), 1999.
[6] Aziz. H. Sharifah, Ansell. P. Martin, Clarke. J. Simon., Panteny. R. Simon. "Modified Polyester Resins for natural fiber composites", Composite Science and Technology, Vol. 65, P.P(525- 535), 2005.

[7] Marandi. S. M., bagheripour. M. H., Rahgozar. R. and Zare. H.,"Strength and Ductility of randomly distributed Palm Fibers Reinforced Silty-sand Soils", American Journal of Applied Science Vol.5, No.3, P.P.(209-220), 2008.

[8] Mathew Philip, Bill Bolton, "Technology of Engineering Materials", Oxford, Boston, Amsterdam, New York 2002.

[9] Rajput, R. A. "A text book of Material Science", $6^{\text {th }}$ edition, Sanjeev kumar kataria for S.K. kataria and Senc, 2004.

[10] Anand R. sanadi, Daniel F. Caulfield, and Rodney E. Jacobson, "Agro- Fiber Thermoplastic Composites", www.fpI.Fs.Fed.us/documents/pdf1997/sanad 97b.pdf

[11] A.K. Bledzki, J.Gassan, "Composites reinforced with cellulose based fibers", Journal of Progress in polymer science, Vol. 24, P.P (221-274), 1999.

[12] Sreekala, M.S., J.George, M.G. Kumaran and S. Thomas, "The mechanical performance of hybrid phenolformaldehyde-based composites reinforced with glass and oil palm fibers", Composite. Science technology Vol. 62, P.P (339353), 2002.

[13] X. Li, S.A. Panigrahi, L.G. Tabil, W.J. Crerar, "Flax Fiber-reinforced Composites and the Effect of Chemical Treatments on their Properties", The Society for engineering in agricultural, food, and biological system, Paper Number: MB04305, 2004.

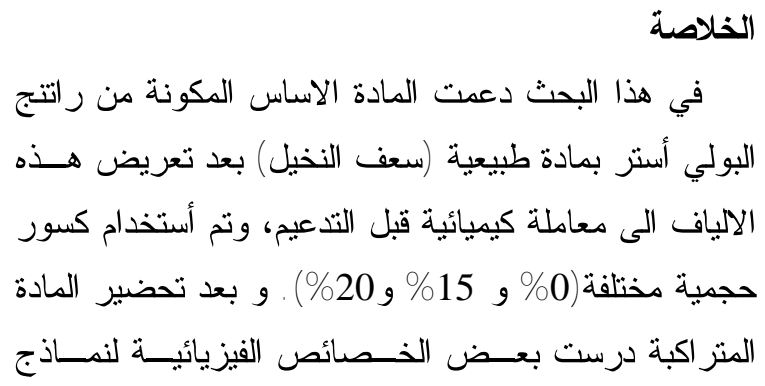


المتر اكبات المحضرة. أذ تم أجر اء أختبــار متانـــة الــشد

و أختبار الصدمة وأختبار التوصيلية الحرارية.

قد تبين من خلال الدراسة أن قيم التوصيلية الحراريــة

تزداد مع زيادة الكسر الحجمي للنماذج. كما لوحظ أن كـلـل

من متانة الثد ومنانة الانحناء تقل بزيادة الكــسر الحجمـي

للألياف . بينما تزداد متانة الصدمة عند زيادة التدعيم بنسبة

15\% لكن مع أستمر ار التدعيم تقل متانة الصدمة ، كمــا إن

المعاملة الكيميائية للألياف تحسن من الخصائص الميكانيكية

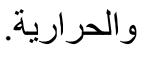

